\title{
THE DISTRIBUTION AND DIVERSITY OF BUTTERFLIES (LEPIDOPTERA: RHOPALOCERA) IN VARIOUS URBAN FORESTS IN NORTH MINAHASA REGENCY, NORTH SULAWESI PROVINCE, INDONESIA
}

\author{
KONERI, R. ${ }^{1 *}-$ MAABUAT, P. V. ${ }^{1}-$ NANGOY, M.-J. ${ }^{2}$ \\ ${ }^{1}$ Department of Biology, Sam Ratulangi University, Campus Sam Ratulangi University Street, \\ Bahu, Manado, North Sulawesi, 95115, Indonesia \\ (phone: +62-813-4027-5276) \\ ${ }^{2}$ Department of Animal Production, Sam Ratulangi University, Campus Sam Ratulangi \\ University Street, Bahu, Manado, North Sulawesi 95115, Indonesia \\ (phone: +62-812-4239-9445) \\ *Corresponding author \\ e-mail: ronicaniago@unsrat.ac.id
}

(Received 20 $0^{\text {th }}$ Oct 2019; accepted $23^{\text {rd }}$ Jan 2020)

\begin{abstract}
The establishment of urban forests are the way to reduce the impact of urban development on biodiversity. This study aimed to analyze the distribution and diversity of butterflies in various urban forests in North Minahasa Regency, North Sulawesi, Indonesia. Butterfly sampling was conducted in four urban forests. The sampling employed the sweeping technique following a the transect line. The results obtained included as many as 5 families of butterfly, consisting of 56 species and 985 individuals. Using the distribution pattern of butterfly species based on the Morisita index, 52 species were found classified as aggregate. The highest species diversity was found in the Kuwil City Forest. Diversity of butterfly species was negatively correlated with air temperature, light intensity, and wind speed. According to the similarity index of the butterfly species community, it was found that the Kaki Dian City Forest, Kenangan City Forest, and Kuwil City Forest shared a high similarity, while the Talise City Forest did not share many similarities with the other urban forests. The diversity of butterflies in urban forests was influenced by the surrounding area, the complexity of the composition of vegetation structures, water availability, and abiotic environmental factors.
\end{abstract}

Keyword: aggregate, environmental, Morisita, sweeping technique, vegetation structures

\section{Introduction}

Developing facilities and infrastructure in urban environments can support the activities of local dwellers and will improve the economy of the urban area, but urban development and human activity can also cause environmental quality to decline. This is because the urban area is filled with built-up area, while many green open spaces have been converted into areas of offices, settlements, trade, industry, ports, airports, and other urban infrastructure (Kusmana, 2015). Land-use change in urban areas raises various environmental problems and can affect and threaten the existence of biotic communities within it (Azahra et al., 2016). Land-use change can also have an impact on biodiversity (Bergerot et al., 2011; Lee et al., 2015).

Plants and animals that live in urban ecosystems often experience local extinction due to loss of habitat, habitat degradation, and fragmentation (McKinney, 2002; Clarket et al., 2007). Some studies reported that species composition and species abundance, such as bird abundance (Motegi and Yanai, 2005; Rubèn and Ian, 2009), ant abundance 
(Lee and Kwon, 2013), and butterfly abundance (Bergerot et al., 2011; Lee and Kwon, 2012), are lower in urban areas than in rural areas.

The establishment of urban forests is one of the efforts to reduce the impact of urban land-use change on biodiversity. According to Law No. 63 of 2002, urban forests serve to improve and maintain the microclimate and aesthetic value, absorb water, create a balance and harmony of the physical environment of the city, and support the preservation of biodiversity. Urban forests also have potential as a means of conserving biodiversity, including the butterfly community (Azahra et al., 2016).

Butterflies that live in urban ecosystems have a very important role in maintaining biodiversity. Adult butterflies help pollinate flowering plants so that the natural propagation process of plants can occur (Borror et al., 1992; Speight et al., 1999; Plona, 2002; Perveen and Haroon, 2015). Butterflies can also be used as bioindicators of environmental change because they are easily surveyed, quickly react to changes in the environment, and have high mobility and preferences for certain habitats (Lee et al., 2014; Dennies et al., 2017). Butterflies are also easily recognizable both taxonomically and ecologically (Kim et al., 2012).

Most butterfly species are cosmopolitan so that they can be found in various types of habitats, from forest to urban areas, and in various environmental conditions (Braby, 2004; Koh and Sodhi, 2004). The biggest threat to the survival of butterflies is humans. The beauty of colorful butterfly wings attracts people's attention and interest to collect them. Land conversion, tree felling, housing development, pollution, and the use of insecticides and herbicides contribute to the extinction of butterflies. Butterflies lose their host plant and lack food due to these environmental changes (Handayani et al., 2015; Thangjam et al., 2018).

Urban forest as one of the butterfly habitats in urban areas has a high conservation value, but on the other hand, the environmental disturbance that occurs indicates the causes of various changes in the environmental conditions of the urban forest that have an impact on the communities in it, including the butterfly community. Thus, habitat protection is very important to support the survival of butterflies. The existence of urban forests in North Minahasa Regency can be an effort to preserve biodiversity, one of which is butterflies.

The existence and availability of data regarding the distribution and diversity of butterflies in urban forests in North Minahasa have a crucial meaning in the initial steps of conservation of butterfly species in urban areas. Research on butterflies in urban forests in North Minahasa Regency has never been conducted before, so there are no detailed and published data on the distribution and diversity of butterflies. Considering the important role of butterflies in an ecosystem, research on the distribution and diversity of butterflies in various urban forests in North Minahasa Regency needs to be conducted. This study aims to analyze the distribution and diversity of butterflies (Lepidoptera: Rhopalocera) in various urban forests in North Minahasa Regency, North Sulawesi Province.

\section{Materials and methods}

\section{Study area and types of urban forests}

This research was conducted from May 2019 to August 2019. Sampling locations were four urban forests, namely, Kuwil City Forest, Talise City Forest, Kenangan City Forest, and Kaki Dian City Forest, in North Minahasa Regency, North Sulawesi 
Province, Indonesia (Fig. 1). The locations of this research were four urban forests in North Minahasa Regency. The selection of locations was based on city forests that have been commissioned through North Minahasa District Regulation Number 2 of 2012 concerning urban forests.

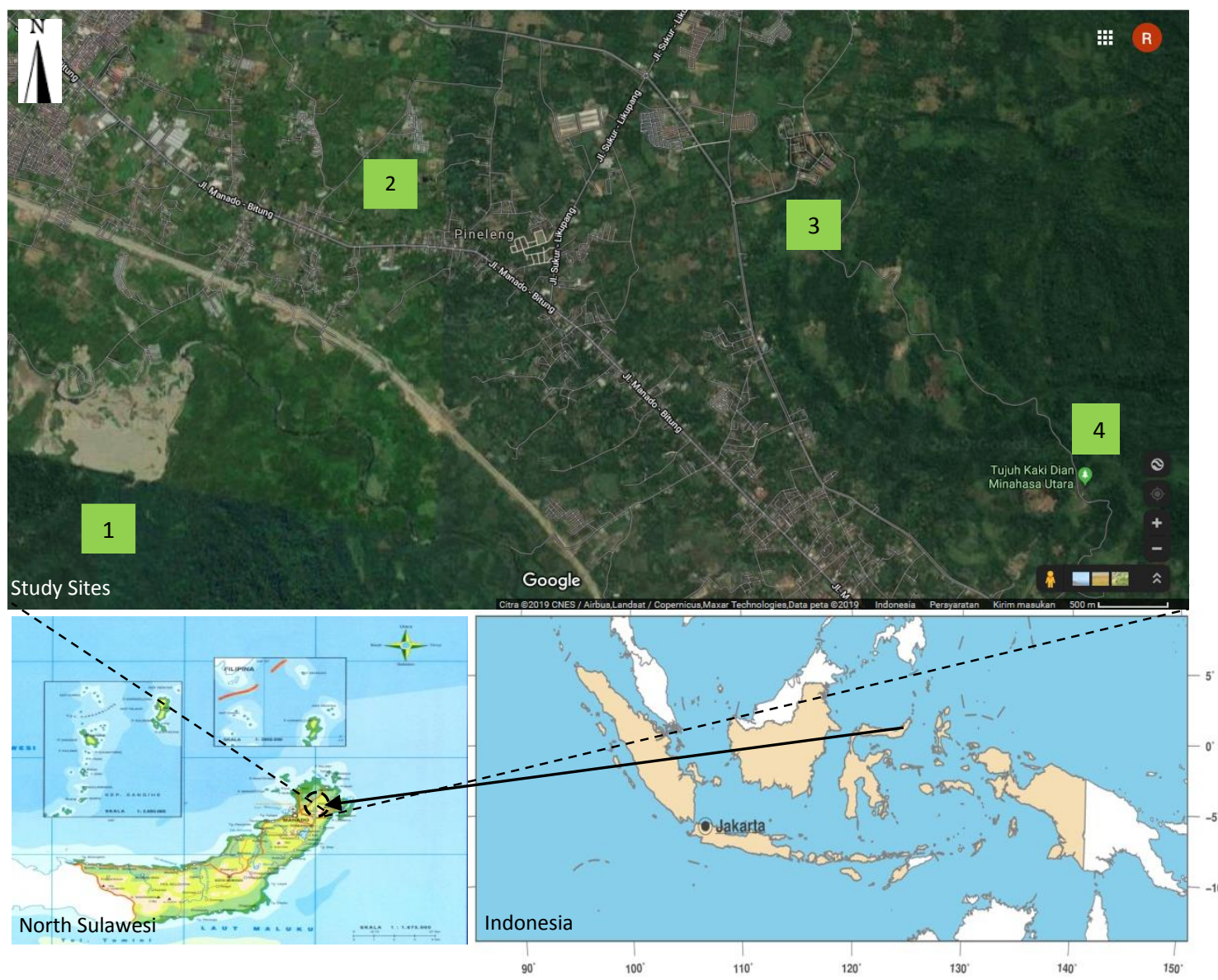

Figure 1. Map of the study area in North Minahasa Regency (1. Kuwil City Forest, 2. Talise City Forest, 3. Kenangan City Forest, 4. Kaki Dian City Forest)

Descriptions of the four urban forests are as follows:

1. Kaki Dian City Forest, which is located in Airmadidi Urban Village in the Mount Klabat forest area and covers an area of $\pm 37 \mathrm{Ha}$. The forest types that surround this urban forest are secondary forests and primary forests in protected forest areas. Vegetation cover is dominated by tall trees with medium diameter. The plant species found were dominated by species from the family Moraceae (genus Ficus) and Anacardiaceae, followed by species from the family Euphorbiaceae (Fig. 2a,b). The coordinates of the sampling points in the Kaki Dian City Forest were transect 1 N: 01²6'12.49”' E: 12459'32.46”, transect $2 \mathrm{~N}$ : $01^{\circ} 26^{\prime} 12.72 \mathrm{E}: 124^{\circ} 59 ; 34.58$; transect $3 \mathrm{~N}: 01^{\circ} 26^{\prime} 18.25^{\prime \prime} \mathrm{E}$ : $124^{\circ} 59^{\prime} 32.66$, and transect $4 \mathrm{~N}$ : 01 ${ }^{\circ} 26^{\prime} 00.69^{\prime \prime} \mathrm{E}$ : $124^{\circ} 59^{\prime} 40.35^{\prime}$ '. The air temperature in this urban forest ranged from 28.0 to $31.6^{\circ} \mathrm{C}$, humidity ranged from 61 to $67.0 \%$, light intensity ranged from 599.0 to 725.0 lux, wind speed 
ranged from $0 \mathrm{~m} / \mathrm{s}$ to $0.8 \mathrm{~m} / \mathrm{s}$, with altitudes between 553 masl and 654 masl (Table 1).

2. Kenangan City Forest, which is located in the area of the North Minahasa Regency Government office, covering an area of \pm 15 ha. The area around Kenangan City forest is office center and plantation land. Vegetation that covers this urban forest consists of a collection of trees that were intentionally planted and native trees at that location (Fig. 2c, d). The coordinates of sampling in the Kenangan City Forest were transect $1 \mathrm{~N}$ : $01^{\circ} 27^{\prime} 23.17^{\prime \prime} \mathrm{E}$ : $124^{\circ} 58^{\prime} 27.04^{\prime \prime}$, transect $2 \mathrm{~N}: 01^{\circ} 27^{\prime} 23.17^{\prime \prime} \mathrm{E}: 1^{\circ} 4^{\circ} 58^{\prime} 27.04^{\prime \prime}$, transect $3 \mathrm{~N}$ :

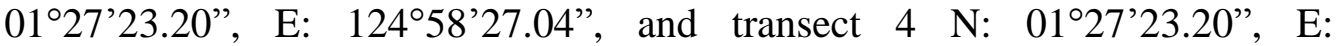
$124^{\circ} 58^{\prime} 27.04^{\prime \prime}$. The air temperature in this urban forest ranged from 31.3 to $32.6{ }^{\circ} \mathrm{C}$, humidity ranged from 58.0 to $61.5 \%$, light intensity ranged from 789.0 to 955 lux, while wind speed ranged from 1.0 to $1.9 \mathrm{~m} / \mathrm{s}$ with altitudes between 295 to $372 \mathrm{~m}$ asl (Table 1).

3. Kuwil City Forest, which is located in Kuwil Village, Kalawat District, covering an area of $\pm 43 \mathrm{Ha}$. The area around this urban forest is plantation land and settlements (Fig. 2e, f). The sampling coordinates of the Kuwil City Forest were transect $1 \mathrm{~N}$ : 01 ${ }^{\circ} 26^{\prime} 17.80^{\prime}$ " E: $124^{\circ} 55^{\prime} 61.67^{\prime \prime}$, transect $2 \mathrm{~N}$ :

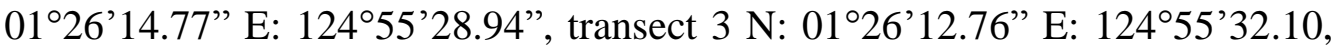
and transect $4 \mathrm{~N}$ : $01^{\circ} 26^{\prime} 12.49^{\prime \prime} \mathrm{E}: 124^{\circ} 55^{\prime} 53.16^{\prime \prime}$. The air temperature in this urban forest ranged from 28.5 to $29.6{ }^{\circ} \mathrm{C}$, humidity ranged between 74.0 and $75.0 \%$, intensity light ranged from 548.0 to 722.0 lux, wind speed ranged from 0 to $0.1 \mathrm{~m} / \mathrm{s}$ with altitude between 95 and $119 \mathrm{~m}$ asl (Table 1).

4. Talise City Forest, which is located in Kolongan Village, Kalawat District, covering an area of $\pm 6 \mathrm{Ha}$. The area around this urban forest is fish ponds, plantations, and settlements (Fig. $2 g$, h). The sampling coordinates of the Talise City Forest were transect 1 N: $01^{\circ} 27^{\prime} 36.43^{\prime \prime}$ E: $124^{\circ} 56^{\prime} 27.70^{\prime \prime}$, transect $2 \mathrm{~N}: 01^{\circ} 27^{\prime} 34.01^{\prime \prime} \mathrm{E}: 1^{\circ} 56^{\prime} 29.09^{\prime \prime}$, transect $3 \mathrm{~N}: 01^{\circ} 27^{\prime} 30.96^{\prime \prime} \mathrm{E}$ : $124^{\circ} 56^{\prime} 22.42^{\prime \prime}$, and transect $4 \mathrm{~N}: 01^{\circ} 27^{\prime} 29.04^{\prime \prime} \mathrm{E}: 1^{\circ} 4^{\circ} 56^{\prime} 24.21^{\prime \prime}$. The temperature of the city forest ranged from 32.2 to $33.0^{\circ} \mathrm{C}$, humidity ranged from 46.5 to $50.0 \%$, the light intensity ranged from 850 to 962.5 lux, with altitudes between 147 and $166 \mathrm{~m}$ asl (Table 1).

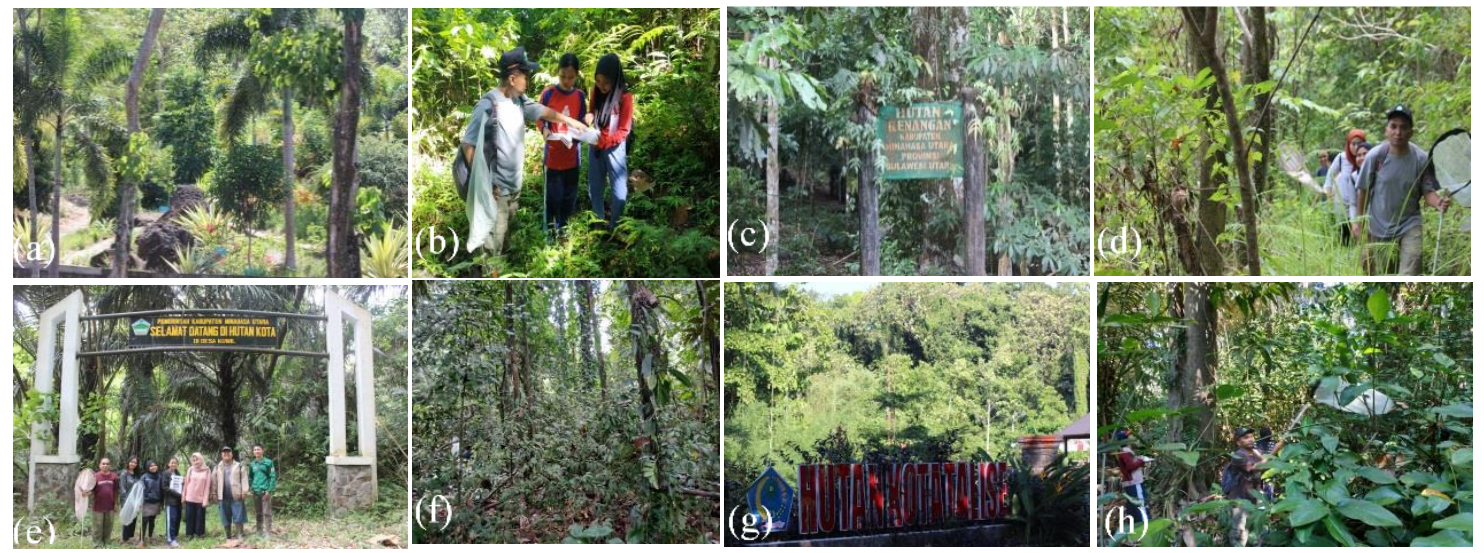

Figure 2. Some photos of sampling site: Kaki Dian City Forest $(a, b)$, Kenangan City Forest (c, $d)$, Kuwil City Forest (e f), Talise City Forest $(g, h)$ 


\section{Sampling and identification of butterfly samples}

Sampling employed the purposive random sampling method. In each type of urban forest, four transect lines were made with a length of $300 \mathrm{~m}$ each. Sampling was conducted along the transect line using butterfly net (sweep net). Butterfly sampling was conducted for 4 days every month for 4 months. Sampling was performed every month for four months. Sampling was done monthly for 4 months. Butterfly sampling for 4 months was quite representative and can provide information about the diversity of butterflies in urban forests of North Minahasa Regency. This is because those four months were during dry season when the weather conditions were sunny. Those conditions were very suitable for butterflies to live. During this period, most of nectarrich plants began to flower, thus providing butterflies food sources and supporting the life and breeding of butterflies"

Table 1. The environmental factor in four urban forests in North Minahasa Regency

\begin{tabular}{c|c|c|c|c|c|c}
\hline \multirow{2}{*}{ Urban forest } & Transect & \multicolumn{5}{|c}{ Environmental factors } \\
\cline { 3 - 7 } & & $\begin{array}{c}\text { Temperature } \\
\left({ }^{\circ} \mathbf{C}\right)\end{array}$ & $\begin{array}{c}\text { Humidity } \\
\mathbf{( \% )}\end{array}$ & $\begin{array}{c}\text { Light } \\
(\mathbf{L u x})\end{array}$ & $\begin{array}{c}\text { Wind } \\
(\mathbf{m} / \mathbf{s})\end{array}$ & $\begin{array}{c}\text { Altitude } \\
(\mathbf{M} \text { asl) }\end{array}$ \\
\hline Kaki Dian & 1 & 28.00 & 61.00 & 599.00 & 0.80 & 591.00 \\
Kaki Dian & 2 & 31.60 & 65.00 & 648.00 & 0.50 & 597.00 \\
Kaki Dian & 3 & 30.00 & 67.00 & 725.00 & 0.50 & 654.00 \\
Kaki Dian & 4 & 31.50 & 65.00 & 648.00 & 0.00 & 553.00 \\
Average \pm St dev & & $30.28 \pm 1.68$ & $64.50 \pm 2.52$ & $655.0 \pm 57.07$ & $0.45 \pm 0.33$ & $598.75 \pm 41.67$ \\
\hline Kenangan & 1 & 31.30 & 58.00 & 824.00 & 1.45 & 295.00 \\
Kenangan & 2 & 32.00 & 58.67 & 789.00 & 1.87 & 295.00 \\
Kenangan & 3 & 32.60 & 61.50 & 859.00 & 1.35 & 325.00 \\
Kenangan & 4 & 32.00 & 60.00 & 955.00 & 1.00 & 372.00 \\
Average \pm St dev & & $31.98 \pm 0.53$ & $59.54 \pm 1.55$ & $856.75 \pm 71.46$ & $1.42 \pm 0.36$ & $321 \pm 36.36$ \\
\hline Kuwil & 1 & 29.00 & 75.00 & 548.00 & 0.10 & 97.00 \\
Kuwil & 2 & 28.50 & 75.00 & 559.00 & 0.20 & 95.00 \\
Kuwil & 3 & 29.50 & 74.00 & 722.00 & 0.00 & 106.00 \\
Kuwil & 4 & 29.60 & 75.00 & 620.00 & 0.10 & 119.00 \\
Average \pm St dev & & $29.15 \pm 0.51$ & $74.75 \pm 0.50$ & $612.25 \pm 79.73$ & $0.10 \pm 0.08$ & $104.25 \pm 10.94$ \\
\hline Talise & 1 & 33.00 & 46.50 & 887.00 & 1.45 & 152.00 \\
Talise & 2 & 32.50 & 50.00 & 850.00 & 1.80 & 153.00 \\
Talise & 3 & 32.15 & 48.00 & 942.00 & 2.00 & 166.00 \\
Talise & 4 & 32.95 & 49.50 & 962.00 & 1.40 & 147.00 \\
Average \pm St dev & & $32.65 \pm 0.40$ & $40.50 \pm 1.58$ & $910.25 \pm 51.18$ & $1.66 \pm 0.29$ & $154.50 \pm 8.10$ \\
\hline
\end{tabular}

Samples were taken at 08.00-14.00 Central Indonesia Time $($ GMT + 8). The collection of butterfly samples was conducted during the day, because butterflies are active only during the day. Only one specimen per species was collected. If the same species was accidentally caught, the butterfly would be released.

The process of identifying specimens used identification books. The identification books used were Butterflies of the South East Asian Island, Part I Papilionidae, Part II Pieridae-Danaidae, Part III Satyridae-Lybytheidae, Part IV Nympalidae (I), Part V 
Nympalidae (II) (Tsukada and Nishiyama, 1981, 1982a, b; 1985, 1991), Insects of the Mount Halimun National Park in the Western Part of Java (Amir et al., 2003), Practical Guide of Butterflies in the Bogor Botanical Garden (Peggie and Amir, 2006), Agricultural Entomology (Jumar, 2000).

In taking samples, environmental factors were also measured. Environmental factors included air temperature and humidity, which were measured using a Thermohygrometer (Deko 637 Thermo-hygrometer), wind speed, which was measured using Anemometer, and light intensity, which was measured using a Lux meter (Lutron LM8010 Type K). Meanwhile, the altitude and coordinates were determined using the Global Positioning System (Garmin GPSMAP 78s).

\section{Data analysis}

Analysis of observational data included the distribution of butterfly species, species diversity, correlation between species diversity and environmental factors, and similarity index of butterfly species between urban forests. The distribution of butterfly species was calculated using the Morisita index according to Krebs (1999):

$$
\text { Morisita Index }(\mathrm{Id})=\mathrm{n}\left(\frac{\sum X^{2}-N}{N(N-1)}\right)
$$

Annotation: Id: Morisita disperse index; n: number of plots; $x$ : number of individuals per plot; $\sum^{X^{2}}=$ sum of squares of all species for each plot; $\mathrm{N}$ : total number of individuals with the following conditions: $\mathrm{Id}=1$ distribution pattern is classified as random (random), Id $>1$ distribution pattern is classified as aggregate, and $\mathrm{Id}<1$ distribution pattern is classified as uniform.

Species diversity was calculated using the species richness index, species diversity index, and species evenness index. Species richness was calculated using the Margalef richness index (R1) with the formula:

$$
\mathrm{RI}=\frac{s-1}{\log N}
$$

Annotation: RI: Richness Index, S: Number of species (n1, n2, n3, ...), N: total individuals in sampling. According to Magurgan (1988), the criteria used to interpret richness were: $\mathrm{RI}<3.5$ : low species richness, $\mathrm{RI}=3.5-5$ : moderate species richness, RI > 5: high species richness.

The species diversity index was calculated using the Shannon-Wiener index (Ludwig and Reynold, 1988):

$$
\mathrm{H}^{\prime}=-\sum_{i=1}^{s}\left(P_{i} \ln P_{i}\right)
$$

Annotation: $\mathrm{Pi}=\mathrm{ni} / \mathrm{N} ; \mathrm{H}^{\prime}$ : Shannon-Wiener diversity index, ni: number of individuals per species; N: number of individuals of all species. The criteria used to interpret the species diversity index, according to Magurran (1988), were: $H^{\prime}<1.5$ : low diversity, $\mathrm{H}^{\prime}=1.5-3.5$ : moderate diversity, $\mathrm{H}^{\prime}>3.5$ : high diversity.

Meanwhile, species evenness employed Shannon evenness index (E) (Magurran, 2004): 


$$
E=\frac{H^{x}}{\operatorname{In} \cdot S}
$$

Annotation: E: evenness index, H': Shannon-Wiener diversity index, S: number of species (n1, n2, n3, ...). Magguran (1988) stated that the criteria used to interpret evenness were: E' < 0.3: low evenness, E' 0.3 - 0.6 : moderate evenness, E'> 0.6: high evenness.

Furthermore, species dominance (D) was calculated by Simpson index to determine the level of dominance of certain species of butterflies in a community (Magurran, 1988). The formula used to calculate dominance was:

$$
\mathrm{D}=\Sigma(\mathrm{ni} / \mathrm{N})^{2}
$$

Annotation D: dominance index, ni: number of individuals of k-I species, N: total number of individuals. Indicators of the dominance index are if $\mathrm{D}=0.00-0.50$, it means the dominance is low. If $0.50<\mathrm{D}<0.75$, it indicates moderate dominance. Whereas, $0.75<\mathrm{D}<1.0$ shows high dominance.

To determine the relationship between species diversity (species richness index, species diversity index, species evenness index, and species dominance index) and environmental factors (air temperature, air humidity, light intensity, wind speed and altitude), Spearman rank correlation was performed. Correlation test used the Statistica program version 6 (Stat Soft, 2001).

To find out the similarity of butterfly communities between urban forests, Sørensen similarity index was used and the data used were the presence and absence of butterfly species (Magurran, 1988). The index was calculated using Biodiv 97, which is a macro software on Excel (Shahabuddin et al., 2005). Dissimilarity value (1-Sørensen index) was used to make two-dimensional ordination of all samples using multidimensional scaling (MDS) and dendrogram (Schulze and Fiedler, 1998). The similarity of butterfly communities between urban forests was calculated based on the Sørensen similarity index. The data used were data on species and species abundance of each habitat type (Cheng, 2004).

Sørensen dissimilarity matrix was then used to create MDS (Multidimensional Scaling) and dendrogram of butterfly species similarity. Multidimensional Scaling (MDS) was used to describe similarities or distances of some observed objects. The result of MDS analysis was a two-dimensional mapping of the objects of observation. MDS arranged the location of the observation objects so that it had the right placement on a two-dimensional map based on the similarity or dissimilarity matrix that has been inputted. After the two-dimensional map was obtained, the distance of the objects of observation could be seen (Hair et al., 1998 and Cheng, 2004). Dimensions functioned to describe the relative position between objects. The similarity of butterfly communities between urban forest locations based on the distances depicted in the twodimensional graph (MDS) was analyzed using Statistica for Windows 6 (StatSoft, 2001).

In addition to using MDS, the similarity of butterfly communities between urban forests was also tested by cluster analysis (Krebs,1999; Ludwig and Reynold, 1988). Cluster analysis of each community was arranged hierarchically in the form of a dendrogram. Dendrograms were created using the Statistica for Windows 6 (StatSoft, 2001). Clustering employed the unweighted pair group method with arithmetic mean (UPGMA) and Euclidean distance (Lewis, 2001). 


\section{Results}

\section{Distribution of butterfly species}

In four urban forests, 2 butterfly species distribution patterns based on the Morisita index were found. They are aggregate and uniform distribution patterns. Meanwhile, random distribution pattern was not found. Pattern of aggregate distribution was found in 52 species, while 4 species showed uniform distribution. Butterflies from the family Nymphalidae were found as many as 28 species and included in aggregate distribution pattern, while 2 species, namely, Elymnias hicetas and Lamasia lyncides were classified as uniform distribution. Butterflies from the family Papilionidae were obtained as many as 9 species and had a pattern of aggregate distribution, while one species, namely Papilio demoleus, had a regular distribution. The butterflies of the family Hesperiidae were found as many as one species with aggregate distribution and one species with uniform distribution, while all species from the family Pieridae and the family Lycaenidae were found to have aggregate distribution pattern (Table 2).

\section{Structure and composition of butterfly species}

The butterflies found during the study were 5 families, consisting of 56 species and 985 individuals. The butterfly families found were Nymphalidae, Papilionidae, Pieridae, Lycaenidae and Hesperiidae. The family with the most number of species (30 species) and individuals (57.26\%) was Nymphalidae, followed by Papilionidae, while the family that had the least number was Hesperiidae with 2 species and 8 individuals (Table 3).

Butterfly species of Parthenos sylvia salentia were the most common species found during the study, with a percentage of $12.93 \%$, followed by Troides helena and Ideopsis vitrea oenopsis as many as 73 individuals (7.41\%) (Fig. 3). The fewest species found were Elymnias hicetas, Lamasia lyncides, Papilio demoleus, and Taractrocera luzonensis, each found as many as one individual $(0.10 \%)$ (Table 3 ).

Based on the type of urban forest, as many as 7 species of butterflies could be found in all urban forests. The only butterflies that were found in the Kaki Dian City Forest and not found in other urban forests were 7 species, while the species Euploea eupator was only found in the Kenangan City Forest. Five species were only found in the Kuwil City forest and were not found in other urban forests, while the Euthalia amanda and Arhopala acetes species were only found in the Kuwil City Forest (Table 3).

The highest abundance of butterfly species was found in the Kuwil City Forest, as many as 295 individuals (29.95\%), then followed by the Kaki Dian City Forest, which had an abundance of 282 individuals $(28.63 \%)$. The urban forest that had the least number of individuals was the Kenangan City Forest with a total of 175 individuals (17.77\%) (Table 3).

The number of butterfly families found in the Kuwil City forest, Kenangan City Forest, and Talise City Forest was 5 families, while in the Kaki Dian City Forest was only 4 families. Nymphalidae was predominantly found in all types of urban forest and was most commonly found in the Kuwil City Forest and Talise City Forest (Fig. 4).

\section{Diversity of butterfly species}

The highest abundance and the highest evenness index of butterfly species was found in the Kuwil City Forest, while the lowest abundance and the lowest evenness index was in the Kenangan City Forest. The highest richness index and diversity index of 
species (H') were also found in the Kuwil City Forest, while the lowest richness index and diversity index of species were in Talise City Forest (Fig. 5).

Table 2. Distribution patterns of butterfly species in four urban forests in North Minahasa Regency, North Sulawesi

\begin{tabular}{|c|c|c|c|c|c|c|}
\hline Famili/Species & $\mathbf{N}$ & $\sum x^{2}$ & $\left(\sum x^{2}-N\right)$ & $\mathbf{N}(\mathbf{N}-1)$ & Id & Distribution \\
\hline \multicolumn{7}{|l|}{ Nymphalidae } \\
\hline Parthenos sylvia salentia & 122 & 6532 & 6410 & 14762 & 1.74 & Aggregate \\
\hline Idiopsis vitrea oenopsis & 73 & 2161 & 2088 & 5256 & 1.59 & Aggregate \\
\hline Junonia hedonia intermedia & 63 & 1055 & 992 & 3906 & 1.02 & Aggregate \\
\hline Idiopsis juventa tontoliensis & 60 & 2072 & 2012 & 3540 & 2.27 & Aggregate \\
\hline Idea blanchardii & 28 & 520 & 492 & 756 & 2.60 & Aggregate \\
\hline Ypthima loryma & 26 & 370 & 344 & 650 & 2.12 & Aggregate \\
\hline Lasippa neriphus tawayana & 25 & 323 & 298 & 600 & 1.99 & Aggregate \\
\hline Mycalesis horsfieldi & 15 & 113 & 98 & 210 & 1.87 & Aggregate \\
\hline Danaus ismare alba & 14 & 148 & 134 & 182 & 2.95 & Aggregate \\
\hline Doleschallia polybete celebensis & 13 & 109 & 96 & 156 & 2.46 & Aggregate \\
\hline Euploea algea & 12 & 50 & 38 & 132 & 1.15 & Aggregate \\
\hline Parantica cleona luciplena & 12 & 90 & 78 & 132 & 2.36 & Aggregate \\
\hline Eupleoa eupator & 11 & 121 & 110 & 110 & 4.00 & Aggregate \\
\hline Ypthima nynias & 11 & 65 & 54 & 110 & 1.96 & Aggregate \\
\hline Neptis ida & 10 & 54 & 44 & 90 & 1.96 & Aggregate \\
\hline Pareronia tritaea & 9 & 81 & 72 & 72 & 4.00 & Aggregate \\
\hline Mycalesis janarda & 8 & 50 & 42 & 56 & 3.00 & Aggregate \\
\hline Cyrestis strigata & 6 & 18 & 12 & 30 & 1.60 & Aggregate \\
\hline Danaus genutia & 6 & 36 & 30 & 30 & 4.00 & Aggregate \\
\hline Euthalia aconthea & 6 & 20 & 14 & 30 & 1.87 & Aggregate \\
\hline Faunis menado & 6 & 36 & 30 & 30 & 4.00 & Aggregate \\
\hline Yoma sabina & 6 & 26 & 20 & 30 & 2.67 & Aggregate \\
\hline Euplea leucostictos westwoodi & 5 & 25 & 20 & 20 & 4.00 & Aggregate \\
\hline Mycalesis nicotia & 5 & 25 & 20 & 20 & 4.00 & Aggregate \\
\hline Cyrestis paulinus & 3 & 9 & 6 & 6 & 4.00 & Aggregate \\
\hline Parantica menadensis & 3 & 5 & 2 & 6 & 1.33 & Aggregate \\
\hline Euthalia amanda & 2 & 4 & 2 & 2 & 4.00 & Aggregate \\
\hline Moduza lycone & 2 & 4 & 2 & 2 & 4.00 & Aggregate \\
\hline Elymnias hicetas & 1 & 1 & -3 & 12 & -0.25 & Uniform \\
\hline Lamasia lyncides & 1 & 1 & -3 & 12 & -0.25 & Uniform \\
\hline \multicolumn{7}{|l|}{ Papilonidae } \\
\hline Troides helena & 73 & 2277 & 2204 & 5256 & 1.68 & Aggregate \\
\hline Papilio gigon & 34 & 438 & 404 & 1122 & 1.44 & Aggregate \\
\hline Papilio ascalaphus & 23 & 201 & 178 & 506 & 1.41 & Aggregate \\
\hline Pachliopta polyphonthes & 14 & 108 & 94 & 182 & 2.07 & Aggregate \\
\hline Graphium meyeri & 11 & 51 & 40 & 110 & 1.45 & Aggregate \\
\hline Graphium agamemnon & 6 & 18 & 12 & 30 & 1.60 & Aggregate \\
\hline Papilio blumei & 4 & 16 & 12 & 12 & 4.00 & Aggregate \\
\hline Papilio polytes & 4 & 16 & 12 & 12 & 4.00 & Aggregate \\
\hline Papilio sataspes & 2 & 4 & 2 & 2 & 4.00 & Aggregate \\
\hline Papilio demoleus & 1 & 1 & -3 & 12 & -0.25 & Uniform \\
\hline \multicolumn{7}{|l|}{ Pieridae } \\
\hline Catopsilia pomona flava & 60 & 1254 & 1194 & 3540 & 1.35 & Aggregate \\
\hline Hebomia glaucippe celebensis & 17 & 201 & 184 & 272 & 2.71 & Aggregate \\
\hline Catopsilia scylla asema & 16 & 104 & 88 & 240 & 1.47 & Aggregate \\
\hline Eurema tominia & 6 & 20 & 14 & 30 & 1.87 & Aggregate \\
\hline Appias zarinda & 5 & 13 & 8 & 20 & 1.60 & Aggregate \\
\hline \multicolumn{7}{|l|}{ Lycaenidae } \\
\hline Jamides celeno & 34 & 534 & 500 & 1122 & 1.78 & Aggregate \\
\hline Euchrysops cnejus & 24 & 210 & 186 & 552 & 1.35 & Aggregate \\
\hline Jamides alecto & 23 & 201 & 178 & 506 & 1.41 & Aggregate \\
\hline Nadacuba berenice & 17 & 289 & 272 & 272 & 4.00 & Aggregate \\
\hline Miletus leos & 14 & 70 & 56 & 182 & 1.23 & Aggregate \\
\hline Acytolepsis puspa & 13 & 85 & 72 & 156 & 1.85 & Aggregate \\
\hline Lampides boeticus & 7 & 21 & 14 & 42 & 1.33 & Aggregate \\
\hline Tajuria mantra & 3 & 9 & 6 & 6 & 4.00 & Aggregate \\
\hline Arhopala acetes & 2 & 4 & 2 & 2 & 4.00 & Aggregate \\
\hline \multicolumn{7}{|l|}{ Hesperiidae } \\
\hline Potanthus omaha & 7 & 25 & 18 & 42 & 1.71 & Aggregate \\
\hline Taractrocera luzonensis & 1 & 1 & -3 & 12 & -0.25 & Uniform \\
\hline
\end{tabular}

$\mathrm{N}$ : total number of individuals, $\mathrm{x}$ : number of individuals per plot; $\sum^{\mathrm{X}^{2}}=$ sum of squares of all species for each plot; N: total number of individuals Id: Morisita disperse index) 

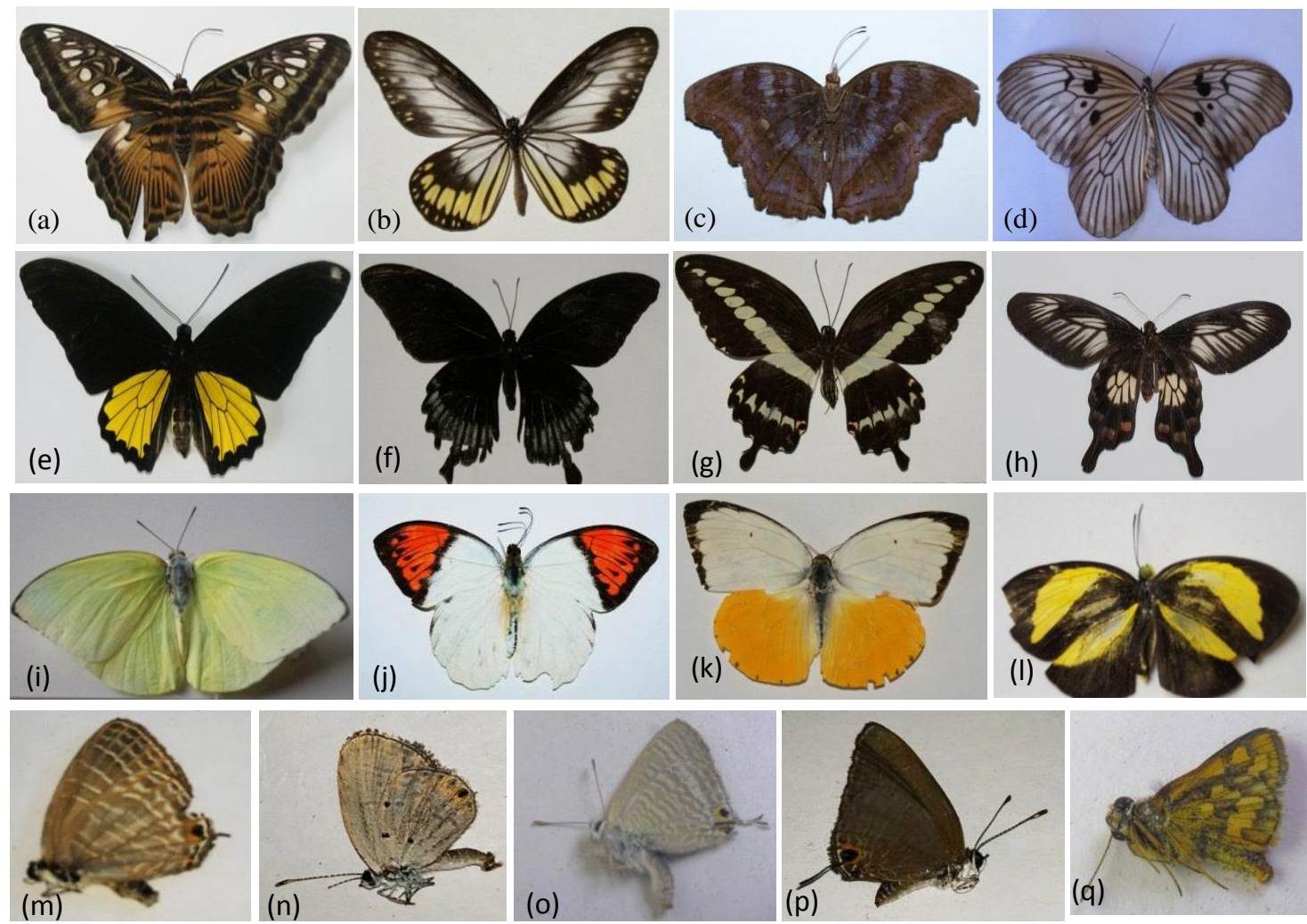

Figure 3. Several species of butterflies in four urban forests in North Minahasa Regency. Nymphlidae: (a) Clipper (P. sylvia), (b) Blanchard's wood nymph (I. vitrea oenopsis), (c) rown pansy (J. hedonia intermedia, (d) Tree nymph (I. blanchardii). Papilionidae: (e) Common birdwing (T. helena), (f) Sulawesi blue mormon (P. ascalaphus), (g) Cream-banded Swallotail (P. gigon) (h). Pachliopta polyphontes). Pieridae: (i) Lemon emigrant (C. pamona flava), (j) Great orange-tip (H. glaucippe celebensis), (k) Orange emigrant (C. scylla asema), (l) Grass yellows (E. tominia). Lycaenidae: (m) Common Cerulean (J. celeno), ( $n$ ) gram blue (E. cnejus),

(o) Metallic cerulean (J. electo), (p) Rounded six-line blue (N. berenice). Hesperiidae: $(q)$ Lesser dart (P. omaha)

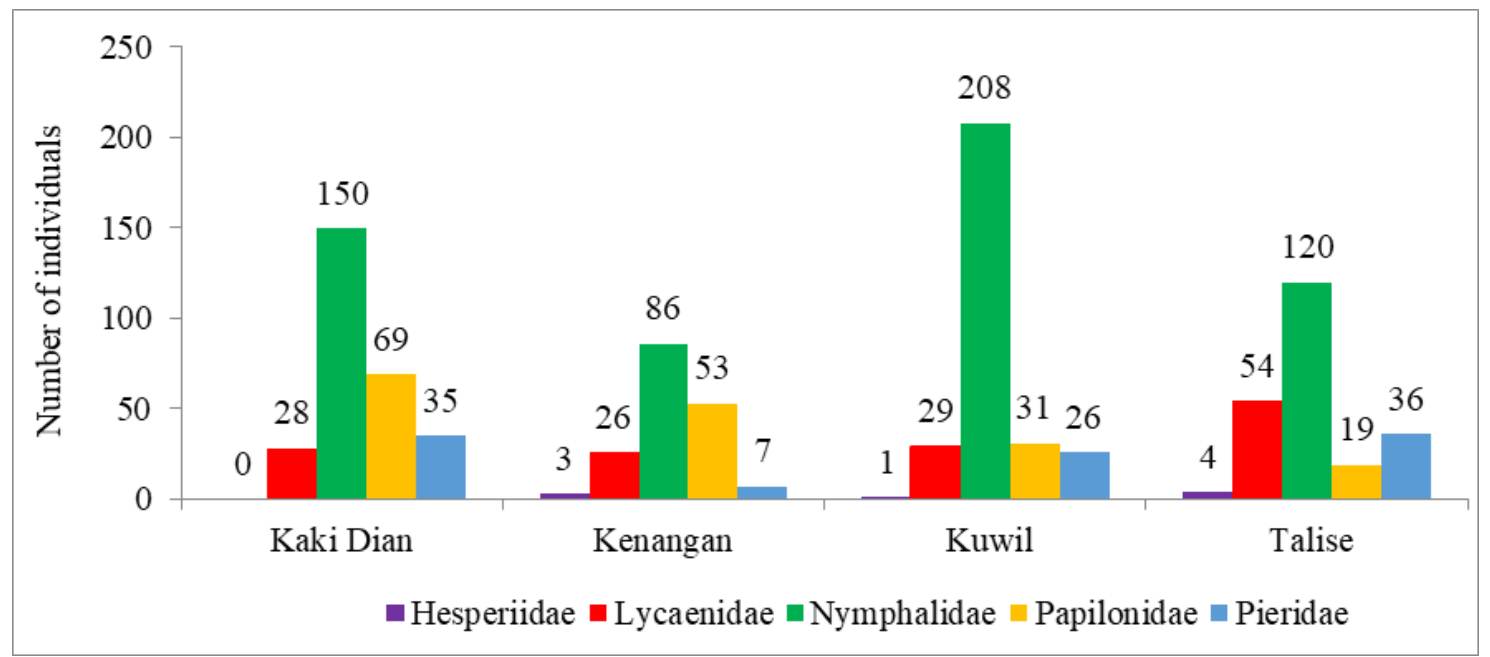

Figure 4. Abundance of family butterflies found in four urban forests at North Minahasa, North Sulawesi 
Table 3. Number of family, species and individuals found in four urban forest in North Minahasa Regency, North Sulawesi

\begin{tabular}{|c|c|c|c|c|c|c|}
\hline \multirow{2}{*}{ Family/ species } & \multicolumn{4}{|c|}{ Urban Forest/ Number of individuals } & \multirow{2}{*}{$\Sigma$} & \multirow{2}{*}{$\%$} \\
\hline & Kaki Dian & Kenagan & Kuwil & Talise & & \\
\hline Nymphalidae & & & & & & \\
\hline Parthenos sylvia salentia & 12 & 0 & 42 & 68 & 122 & 12.39 \\
\hline Idiopsis vitrea oenopsis & 28 & 36 & 9 & 0 & 73 & 7.41 \\
\hline Junonia hedonia intermedia & 15 & 11 & 15 & 22 & 63 & 6.40 \\
\hline Idiopsis juventa tontoliensis & 44 & 6 & 10 & 0 & 60 & 6.09 \\
\hline Idea blanchardii & 6 & 0 & 22 & 0 & 28 & 2.84 \\
\hline Ypthima loryma & 0 & 0 & 17 & 9 & 26 & 2.64 \\
\hline Lasippa neriphus tawayana & 3 & 5 & 17 & 0 & 25 & 2.54 \\
\hline Mycalesis horsfieldi & 0 & 10 & 3 & 2 & 15 & 1.52 \\
\hline Danaus ismare alba & 2 & 0 & 12 & 0 & 14 & 1.42 \\
\hline Doleschallia polybete celebensis & 0 & 0 & 3 & 10 & 13 & 1.32 \\
\hline Euploea algea & 6 & 2 & 3 & 1 & 12 & 1.22 \\
\hline Parantica cleona luciplena & 3 & 0 & 9 & 0 & 12 & 1.22 \\
\hline Euploea eupator & 0 & 11 & 0 & 0 & 11 & 1.12 \\
\hline Ypthima nynias & 0 & 0 & 7 & 4 & 11 & 1.12 \\
\hline Neptis ida & 7 & 1 & 2 & 0 & 10 & 1.02 \\
\hline Pareronia tritaea & 0 & 0 & 9 & 0 & 9 & 0.91 \\
\hline Mycalesis janarda & 0 & 1 & 7 & 0 & 8 & 0.81 \\
\hline Cyrestis strigata & 1 & 1 & 4 & 0 & 6 & 0.61 \\
\hline Yoma sabina & 5 & 1 & 0 & 0 & 6 & 0.61 \\
\hline Danaus genutia & 6 & 0 & 0 & 0 & 6 & 0.61 \\
\hline Euthalia aconthea & 0 & 0 & 4 & 2 & 6 & 0.61 \\
\hline Faunis menado & 6 & 0 & 0 & 0 & 6 & 0.61 \\
\hline Euploea leucostictos westwoodi & 0 & 0 & 5 & 0 & 5 & 0.51 \\
\hline Mycalesis nicotia & 0 & 0 & 5 & 0 & 5 & 0.51 \\
\hline Parantica menadensis & 2 & 1 & 0 & 0 & 3 & 0.30 \\
\hline Cyrestis paulinus & 0 & 0 & 3 & 0 & 3 & 0.30 \\
\hline Euthalia amanda & 0 & 0 & 0 & 2 & 2 & 0.20 \\
\hline Moduza lycone & 2 & 0 & 0 & 0 & 2 & 0.20 \\
\hline Elymnias hicetas & 1 & 0 & 0 & 0 & 1 & 0.10 \\
\hline Lamasia lyncides & 1 & 0 & 0 & 0 & 1 & 0.10 \\
\hline Papilionidae & & & & & & \\
\hline Troides helena & 36 & 31 & 2 & 4 & 73 & 7.41 \\
\hline Papilio ascalaphus & 0 & 11 & 4 & 8 & 23 & 2.34 \\
\hline Papilio gigon & 7 & 8 & 18 & 1 & 34 & 3.45 \\
\hline Pachliopta polyphonthes & 10 & 2 & 2 & 0 & 14 & 1.42 \\
\hline Graphium mayeri & 5 & 1 & 5 & 0 & 11 & 1.12 \\
\hline Graphium agamemnon & 3 & 0 & 0 & 3 & 6 & 0.61 \\
\hline Papilio blumei & 4 & 0 & 0 & 0 & 4 & 0.41 \\
\hline Papilio demoleus & 0 & 0 & 0 & 1 & 1 & 0.10 \\
\hline Papilio polytes & 4 & 0 & 0 & 0 & 4 & 0.41 \\
\hline $\begin{array}{c}\text { Papilio sataspes } \\
\text { Pieridae }\end{array}$ & 0 & 0 & 0 & 2 & 2 & 0.20 \\
\hline Catopsilia pomona flava & 18 & 5 & 8 & 29 & 60 & 6.09 \\
\hline Hebomia glaucippe celebensis & 2 & 0 & 14 & 1 & 17 & 1.73 \\
\hline Catopsilia scylla asema & 8 & 0 & 2 & 6 & 16 & 1.62 \\
\hline Eurema tominia & 4 & 2 & 0 & 0 & 6 & 0.61 \\
\hline $\begin{array}{c}\text { Appias zarinda } \\
\text { Lycaenidae }\end{array}$ & 3 & 0 & 2 & 0 & 5 & 0.51 \\
\hline Jamides celeno & 4 & 3 & 5 & 22 & 34 & 3.45 \\
\hline Euchrysops cnejus & 11 & 2 & 2 & 9 & 24 & 2.44 \\
\hline Jamides alecto & 0 & 11 & 8 & 4 & 23 & 2.34 \\
\hline Nadacuba berenice & 0 & 0 & 0 & 17 & 17 & 1.73 \\
\hline Miletus leos & 3 & 6 & 5 & 0 & 14 & 1.42 \\
\hline Acytolepsis puspa & 6 & 0 & 7 & 0 & 13 & 1.32 \\
\hline Lampides boeticus & 1 & 4 & 2 & 0 & 7 & 0.71 \\
\hline Tajuria mantra & 3 & 0 & 0 & 0 & 3 & 0.30 \\
\hline $\begin{array}{c}\text { Arhopala acetes } \\
\text { Hesperiidae }\end{array}$ & 0 & 0 & 0 & 2 & 2 & 0.20 \\
\hline Potanthus omaha & 0 & 3 & 0 & 4 & 7 & 0.71 \\
\hline Taractrocera luzonensis & 0 & 0 & 1 & 0 & 1 & 0.10 \\
\hline Total & 282 & 175 & 295 & 233 & 985 & 100.00 \\
\hline
\end{tabular}




$$
-2306-
$$
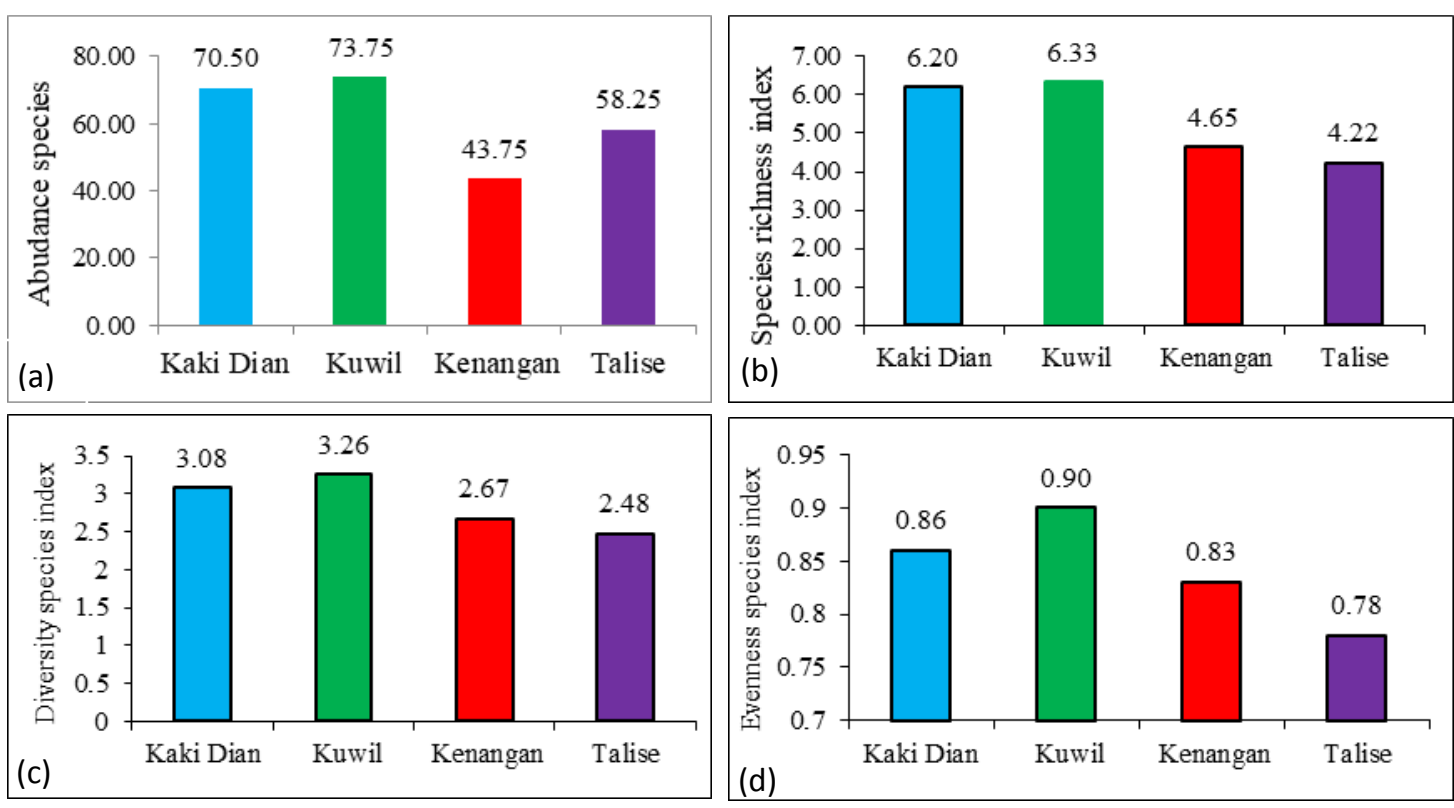

Figure 5. The influence of urban forests types on (a) abundance, (b) richness (c) diversity and (d) evenness spescies index in North Minahasa, North Sulawesi

Based on the categories, it was found that the species richness indices in the Kaki Dian City Forests and Kuwil City Forests were classified as high $(\mathrm{S}>5)$, while the species richness indices in the Kenangan City Forest and Talise City Forest were classified as moderate (S: 3.5-5). The diversity index of butterfly species in the four urban forests was categorized as moderate (H: 1.5-3.5). Meanwhile, the evenness index of butterfly species was categorized as high because the index was greater than 0.6.

\section{Index of species dominance}

The highest dominance index of butterfly species was found in the Talise City Forest, while the lowest dominance index was in the Kuwil City Forest (Fig. 6). Based on the dominance index category, it was found that species dominance in the four urban forests was classified as low dominance $(\mathrm{D}<0.5)$. This showed that no dominant butterfly species was found in the four urban forests.

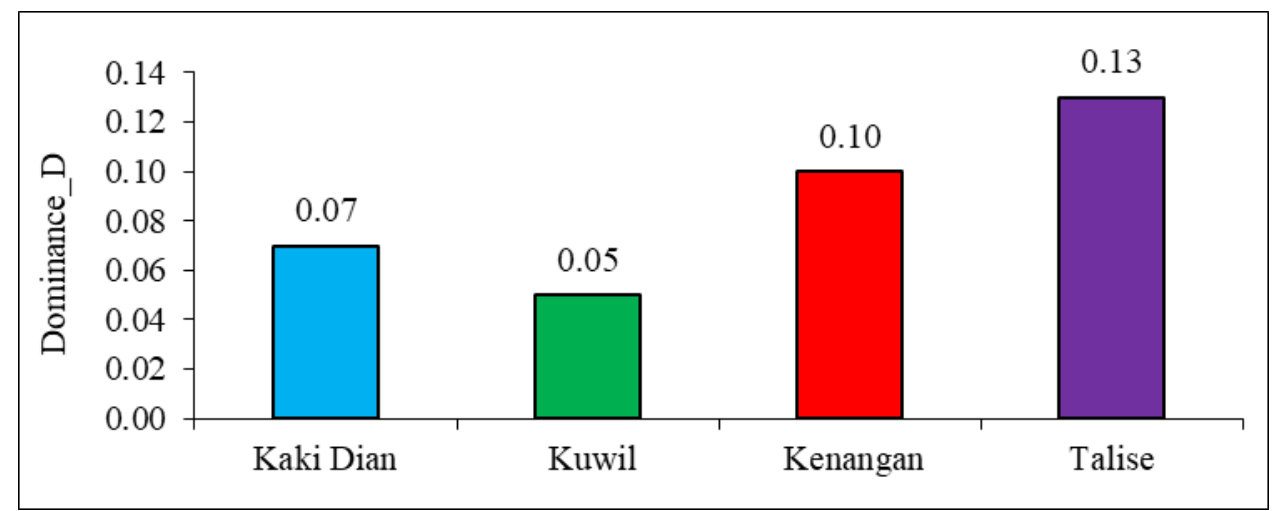

Figure 6. Index of species dominance in four urban forests North Minahasa, North Sulawesi 


\section{Correlation between species diversity and environmental factors}

Correlation of butterfly species diversity with environmental factors showed that there was a negative correlation of species abundance, richness index, diversity index, and species evenness index with air temperature, light intensity, and wind speed (Table 4). The correlation of species abundance, richness index, diversity index, and evenness index of species with air humidity was positive. Dominance index was positively correlated with air temperature, light intensity, wind speed and altitude, while dominance index and air humidity showed a negative correlation (Table 4).

Table 4. Correlation of butterfly species diversity with environmental factors in four urban forests North Minahasa, North Sulawesi

\begin{tabular}{c|c|c|c|c|c}
\hline Variable & Air temperature & Air humidity & Light intensity & $\begin{array}{c}\text { Wind } \\
\text { velocity }\end{array}$ & Altitude \\
\hline Abundance & -0.31 & 0.41 & -0.42 & $-0.56^{*}$ & 0.04 \\
Richness indexes & -0.36 & 0.48 & -0.47 & -0.45 & 0.20 \\
Diversity indexes & $-0.55^{*}$ & $0.57^{*}$ & $-0.66^{*}$ & $-0.59^{*}$ & -0.01 \\
Evenness indexes & $-0.60^{*}$ & 0.46 & $-0.64^{*}$ & -0.46 & -0.23 \\
Dominance indexes & $0.56^{*}$ & -0.47 & $0.67^{*}$ & $0.52^{*}$ & 0.07 \\
\hline
\end{tabular}

*Marked correlations are significant at $\mathrm{p}<.05000 . \mathrm{N}=16$ (Casewise deletion of missing data)

\section{The similarity of the butterfly community in the urban forests}

Analysis of the similarity of the butterfly community in the urban forests using MDS showed that the objects of observation, which were Kota Dian City Forest, Kenangan City Forest, and Kuwil City Forest, had a relatively close distance, while Talise City Forest had a distant point, compared to other urban forests (Fig. 7a). The dendrogram results from the dissimilarity matrix resulted in the Kaki Dian City Forest, the Kenangan City Forest, and the Kuwil City Forest forming one group, while the Talise City Forest separated (Fig. 7b).
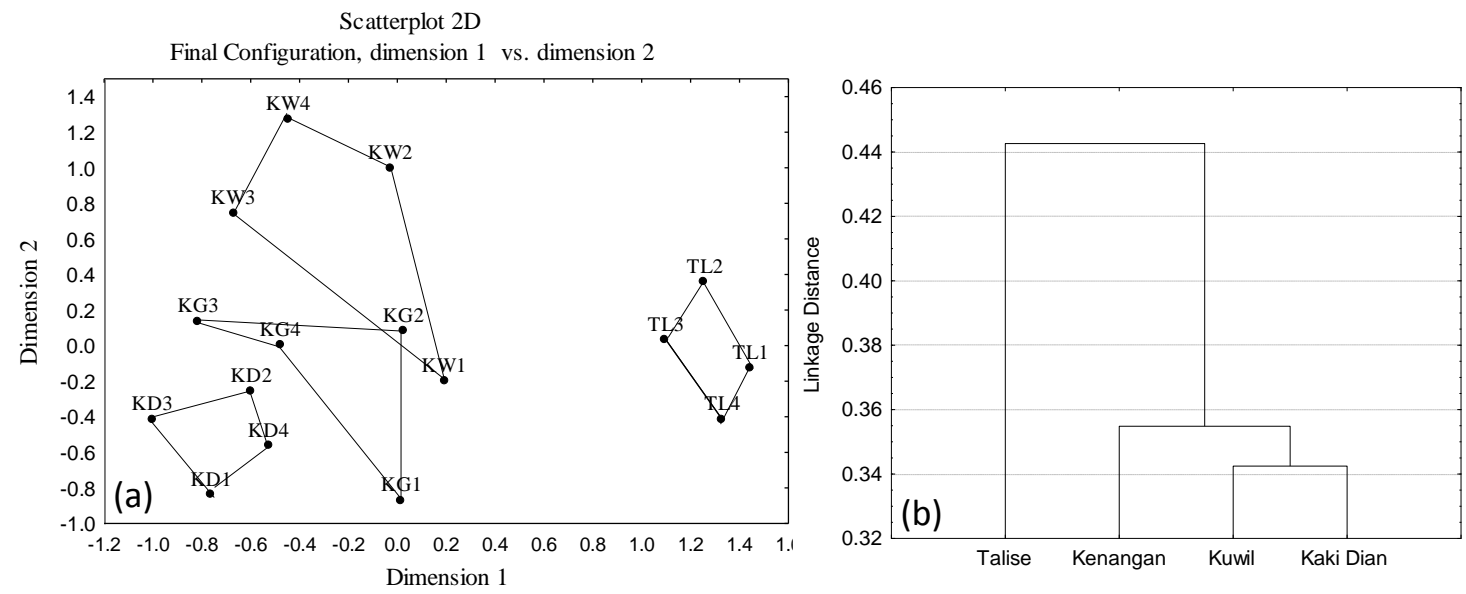

Figure 7. Multidimensional Scaling (a), and dendrogram (b) about butterfly community similarity among urban forests in North Minahasa, North Sulawesi Utara (KD: Kaki Dian City Forest, KG: Kenangan City Forest, KW: Kuwil City Forest, TL: Talise City Forest) 


\section{Discussion}

The number of butterfly species found in four urban forest in Minahasa Regency, North Sulawesi Province, only reached $0.28 \%$ of the 20,000 species of butterflies in the world (Alarape, et al., 2015), 2.80\% of about 2,000 species butterflies found in Indonesia (Peggie, 2014), and $10.19 \%$ of the 557 species of butterflies spread across Sulawesi Island (Vane-Wright and de Jong, 2003). The number of butterfly species found in this research was higher than the number of butterflies found in some butterfly diversity studies in other urban forests. Alfida et al. (2016) obtained 18 species of butterflies in Banda Aceh City Forest. Rahayu and Basukriadi (2012) found 43 species of butterflies in Sabki City Forest in Jambi City. Oktavianti (2019) found 22 species of butterflies in Pontianak City Forest, while Kumar and Rana (2018) reported 30 species of butterflies found in fragmented urban forests in Lucknow, India.

The distribution of butterfly species in four urban forests in North Minahasa Regency, in general, was classified as aggregate distribution. Aggregate distribution pattern is generally found in insects, because of their tendency to aggregate, gathering from various degrees representing the most common characteristics. D'Abrera (1990) reported that butterflies migrated in large numbers (in groups) to a certain direction to find a place that provides enough food for larval development. The aggregation of individual organisms of a population results from responding to changes in daily or seasonal weather and responding to differences in local habitat conditions (Odum, 1996).

The dominant butterfly family found in all forests was Nymphalidae. This result was similar to the results of several studies, including studies by Ramesh et al. (2010), Boonvanno et al. (2000), Sutra et al. (2012), and Koneri and Nangoy (2019). The high abundance of butterflies from the family Nymphalidae was due to the abundant number of individuals from the family throughout the world and their high ability to live. According to Vane-Wright and de Jong (2003), compared to other families, Nymphalidae is a butterfly family with the largest number of species in the world, which is about 6,500 species consisting of 13 sub-families. The butterflies from this family are generally cosmopolitan in nature.

Nymphalidae also has a tendency to be polyphage. Their polyphage nature enables Nymphalidae to be able to meet its food needs even though the main host plants are not available (Lestari et al., 2015). Sreekumar and Balakrishnan (2001) reported that many members of the family Nymphalidae are polyphage. This means that if their main host plants are not available, the butterfly can still use other plants that are suitable for feeding its larvae. Different types of flowering and host plants will invite different types of butterflies to nectar or lay eggs on the suitable host. According to Peggie and Amir (2006), the feed source of the Nymphalidae family is plants from the families Fabaceae, Annonaceae, Asteraceae, and Poaceae.

The family Nymphalidae is easily found all year round. This is because these insects are generalist. Some species of Nymphalidae do not depend on the existence of flower nectar alone. Those species are able to obtain food sources from rotten fruit and urine of other animals (Sarma et al., 2012).

Hesperiidae was a butterfly family with the fewest species and individuals found. This was because this family is small in body size and prefers moist and shady places such as forest areas. In this study, butterflies from the family Hesperiidae were found in all locations of urban forests except in the Kaki Dian City Forest. According to Amir and Kahono (2008), Hesperiidae is usually crepuscular, that is, it is active before night 
or when the light is dim. Observation of butterflies in this research was carried out since morning $(7: 00 \mathrm{pm})$ until late afternoon $(3: 00 \mathrm{pm})$. This condition caused very few encounters with butterflies from the family Hesperiidae.

Parthenos sylvia salentia species had the highest abundance compared to other species. The butterfly species is included in the family Nymphalidae. This species is found in tropical rain forests, usually around rivers. During the observation, many species were found near river basins in the Kuwil City Forest.

The next species of butterfly that had a high abundance was Troides helena, which belongs to the family Papilionidae. Troides helena is included as species protected by Government Regulation No. 7 of 1999, Decree of the Minister of Agriculture No.576/Kpts/Um/8/1980, and Decree of the Minister of Agriculture No.716/Kpts/Um1/0/1980. The species is also included in Appendix II of CITES (Convention of International Trade in Endangered Species). This means that the species is currently not included in the endangered category, but has the possibility of being endangered if the trade of the species is not regulated (Soeharto and Mardiastuti, 2003). Troides helena are poached for sale because of their beauty and scarcity (Noerdjito and Aswari, 2003; Nurjannah, 2010).

Differences in abundance, richness index, diversity index, and evenness index of butterfly species in four urban forests were greatly influenced by the area of urban forests and the complexity of the composition of vegetation structures making up the urban forest. The Kuwil City Forest was the location with the highest species diversity, while the lowest species diversity was in the Talise City Forest. The Kuwil City Forest is the location with the largest area ( \pm 46 ha), compared to the Kaki Dian City Forest ( \pm 37 ha), the Kenangan City Forest ( \pm 15 ha), and the Talise City Forest ( \pm 6 ha), and according to the theory of island biogeography, area is directly proportional to the diversity of species. The large size of an island will support an increase in the population size of the butterfly species due to the availability of food sources and habitats (MacArthur and Wilson, 1967). Island biogeography can be applied to fragmentation of urban forest landscapes as a model of how "islands" as small habitats can adversely affect the biodiversity of their natural habitat (Harris, 1984). Urban forest is considered an "island" in the form of habitat area that is surrounded by other areas that are not suitable for the life of species, such as residential land, offices, and plantations that are intensively processed.

The diversity of butterfly species in urban forests is also influenced by the availability of feed plants and is closely related to physical environmental factors, such as soil, water, temperature, sunlight, and biological factors that include vegetation and other animals. The distribution and abundance of plants as a source of larval feed was one of the factors that had a major influence on the survival of butterfly larvae. Nectarproducing plants also greatly affect the survival of butterflies, because the main food of butterfly is flower nectar. The more liquid nectar is available, the more butterflies come to visit the place. In the Kuwil forest habitat, there are many nectar-producing plants, such as oranges (Rutaceae), soursop (Annona muricata), durian (Durio zibethinus), gmelina (Gmelina arborea), Ficus sp, mango (Mangifera indica), Mussaenda frondosa, Calliandra calothyrsus, Clerodendrum paniculatum, Ageratum conyzoides, and Lantana camara. More diverse vegetation in a habitat has the potential for greater availability of feed for butterflies, compared to less diverse vegetation does (Rahayuningsih, 2012). 
Another factor affecting the diversity of butterflies in urban forests in North Minahasa Regency was the availability of water. Urban forest where water flow can be found was the Kuwil City Forest and this urban forest provides a source of water for the surrounding community. The availability of water sources affects the existence of a type of butterfly, because butterflies like river banks (Amir et al., 2003). Butterflies come to the wet area to get water. Besides needing energy from their food, adult butterflies also need water in their life. Observations in the Kuwil City Forest showed that the source of water that was often visited by butterflies was sandy river banks. Glassberg (2001) argued that most species of butterflies, especially male butterflies, aggregated in moist sand or soil to absorb mineral salts and water. This behavior is called "puddling". The salt will be transferred to the female butterfly during the mating process as additional nutrient for the eggs.

Environmental factors in urban forests, such as air temperature, humidity, light intensity, and wind speed affect the diversity of butterfly species. According to Sharma and Joshi (2009), the structural complexity of habitat and vegetation diversity, including the influences of physical-chemical factors, such as air temperature, air humidity, and light intensity, was correlated with the diversity of insect species. The test results showed that species diversity was negatively correlated with air temperature, light intensity, and wind speed, whereas species diversity and wind speed was positively correlated.

Air temperature was very influential on the diversity of butterflies because these insects are poikilothermic, which means that their body temperature will increase or decrease following the temperature of the surrounding environment (Sihombing, 2002). Each butterfly species has different adaptability to temperature and humidity changes in their habitat. The temperature that can support the life of a butterfly ranges between 16 and $42{ }^{\circ} \mathrm{C}$ (Scoot, 1986), while the optimal temperature for butterflies is around 28 $35^{\circ} \mathrm{C}$ (Watanabe and Imoto, 2003). Based on temperature measurements in the four urban forests, it was found that the temperature in each urban forest could still support butterfly activity.

Furthermore, humidity is a very important climate factor. The correlation test found that the higher the relative humidity in an urban forest was, the higher the diversity of butterfly species in the urban forest became. Humidity can affect the breeding, growth, development, and activeness of insects. The ability of butterfly species to survive in the humidity of the surrounding air is different for each species and for each developmental stage. Air humidity can also affect the growth of host plants and indirectly affect the diversity of butterfly species (Efendi, 2009).

Light intensity influenced the diversity of butterflies. If the intensity of light was higher, the diversity of butterfly species would decrease. This was because the high light intensity caused the air temperature to rise and humidity to drop outside the range of air conditions required by a butterfly. Increased air temperature will accelerate the evaporation of body fluids and endanger the life of a butterfly. Low air humidity will affect butterflies that are large and wide-winged because the greater surface area of the body will increase the evaporation of body fluids. High light intensity also caused the volume of nectar secretions in flowers to decrease (Efendi, 2009).

Meanwhile, wind speed was negatively correlated with the diversity of butterfly species, which meant that if the wind speed got higher, the diversity of butterfly species would decrease. The results of wind speed measurements found that the lowest wind speed was in the Kuwil City Forest. Low wind speeds caused a high diversity of 
butterflies in this urban forest. High wind speed will damage the wings of butterflies, especially butterflies with broad and fragile wings, such as some species of the family Papilionidae and the family Nymphalidae, which will not last long in these conditions.

The similarity index of butterfly species between urban forests showed that the composition of butterfly species in the Kaki Dian City Forest, Kenangan City Forest, and Kuwil City Forest had many similarities, while the composition of butterfly species in the Talise City Forest did not share many similarities with the other urban forests. Species similarity between habitats is influenced by habitat characteristics, especially those characteristics related to plants as food, a place to take shelter from predator attacks, host plants to carry out their life cycle, playgrounds, and physical environmental factors, such as the presence of water flow, humidity, and weather conditions.

\section{Conclusion}

In general, the distribution of the butterfly species found (52 species) have a flocking pattern (aggregate). The butterfly species found consist of 5 families, comprising 56 species and 985 individuals. Butterfly species with the highest abundance is Parthenos silva salentia (29.93\%). Family with the largest number of individuals is Nymphalidae $(57.26 \%)$. The diversity of butterfly species which includes abundance, evenness index, richness index and the index of the highest species diversity was found in the urban forest of Kuwil. The highest domination index of butterfly species was found in the urban forest of Talise. The diversity of butterfly species is negatively correlated with air temperature, light intensity and wind speed. From the butterfly species community similarity index of urban forests, it is found that urban forests of Kaki Dian, Kenangan and Kuwil have a high similarity compared to the urban forest of Talise.

The results of this study recommend that further research on the types of plants that serve as food plants and hosts of butterflies should be done. The research period should include other seasons. It is expected that the Forestry Department of North Minahasa consider the diversity of butterflies in the management of urban forests by maintaining the habitat stability of urban forests. Habitat stability can sustain the butterfly conservation, especially Troides Helena butterflies which are protected and included in Appendix II of CITES (Convention of International Trade in Endangered Species).

Acknowledgements. The author would like to thank the rector of the Sam Ratulangi University, Manado, for funding this research through the scheme of Riset Dasar Unggulan Unsrat (RDUU) with the contract number: SP DIPA - 042.01.2.400959/2019 dated 5 December 2018.

\section{REFERENCES}

[1] Alarape, A. A., Omifolaji, J. K., Mwansat, G. S. (2015): Butterfly species diversity and abundance in University of Ibadan Botanical Garden, Nigeria. - Open Journal of Ecology 5: 352-360.

[2] Alfida, A., Hanum, U., Eliyanti, E. (2016): Butterflies (Rhopalocera) in urban forests are in BNI Banda Aceh. - Journal Biotik 4: 117-127.

[3] Amir, M., Kahono, S. (2008): Butterflies (Lepidoptera). - In: Amir, M., Kahono, S. (eds.) Insects in Halimun Mountain National Park West Region. JICA, Jakarta. 
[4] Amir, M., Noerdjito, W. A., Kahono, K. (2003): Butterflies (Lepidoptera). - In: Amir, M., Kahono, S. (eds.) Insects in Halimun Mountain National Park West Region. JICA, Jakarta.

[5] Azahra, S. D., Masyud, B., Farikhah, N. (2016): Comparison of butterfly communities in various types, characteristics, and environmental disturbance of urban forests. - Media Konservasi 21: 108-115.

[6] Bergerot, B., Fontaine, B., Julliard, R., Baguette, M. (2011): Landscape variables impact the structure and composition of butterfly assemblages along an urbanization gradient. Landscape Ecology 26: 83-94.

[7] Boonvanno, K., Watanasit, S., Permkam, S. (2000): Butterfly diversity at ton Nga-Chang wildlife sanctuary, Songkhla Province, Southern Thailand. - Sci Asia 26: 105-110.

[8] Borror, D. J., Triplehorn, C. A., Johnson, N. F. (1992): Introduction to Insect Lessons. UGM Press, Yogyakarta.

[9] Braby, M. F. (2004): The Complete Field Guide to Butterflies of Australia. - CSIRO Publishing, Collinwood.

[10] Cheng, C. (2004): Statistical approaches on discriminating spatial variation of species diversity. - Botanical Bulletin of Academia Sinica 45: 339-346.

[11] Clark, P. J., Reed, J. M., Chew, F. S. (2007): Effects of urbanization on butterfly species richness, guild structure, and rarity. - Urban Ecosystem 10: 321-337.

[12] D'abrera, B. (1990: Butterflies of the Australian Region. 3rd Ed. - Hill House, Melbourne and London.

[13] Dennis, E. B., Mogan, B. J. T., Roy, D. B., Brereton, T. M. (2017): Urban indicators for UK butterflies. - Ecology Indicators 76: 184-193.

[14] Efendi, M. A. (2009): Diversity of butterflies (Lepidoptera: Ditrysia) in "Corridor Forest", Gunung Halimun-Salak National Park, West Java. - Thesis, School of Post Graduate Studies of Bogor Agricultural University, Bogor.

[15] Glassberg, J. (2001): Butterflies through Binocular the West: A Field Guide to the Butterflies of Western North America. - Oxford University Press, New York.

[16] Hair, J. F. J., Anderson, R. E., Tatham, R. L., Black, W. C. (1998): Multivariate Data Analysis. $5^{\text {th }}$ ed. - Prentice-Hall International, USA.

[17] Handayani, S. A., Bachri, K. S., Ismail, T., Sukmawati, Jasmin, E. I., Shagir, K. Y. (2015): Diversity of Butterly in Bantimurung Bulusaraung National Park. - In: Balai, T. N. (ed.) Bantimurung Bulusaraung. Maros, Sulawesi Selatan.

[18] Harris, L. D. (1984): The Fragmented Forest: Island Biogeography Theory and the Preservation of Biotic Diversity. - University of Chicago Press, Chicago, Illinois.

[19] Jumar (2000): Agricultural Entomology. - Rineka Cipta, Jakarta.

[20] Kim, S. S., Lee, C. M., Kwon, T. S., Joo, H. Z., Sung, J. H. (2012): Korean Butterfly Atlas 1996-2011. - Research Note 461, Korea Forest Research Institute, Korea Disabled Human Good Life Pub. Co, Seoul (in Korean).

[21] Koh, L. P., Sodhi, N. S. (2004): Importance of reserves, fragments, and park for butterfly conservation in a tropical urban landscape. - Ecological Applications 14: 1695-1708.

[22] Koneri, R., Nangoy, M. J. (2019): Butterfly community structure and diversity in Sangihe Islands, North, Sulawesi, Indonesia. - Applied Ecology and Environmental Research 17: 2501-2517.

[23] Krebs, C. J. (1999): Ecological Methodology. Second Ed. - Addison-Wesley, Menlo Park.

[24] Kumar, A., Rana, S. S. (2018): Species diversity and community structure of butterfly in urban forest fragments at Lucknow. - Indian Journal of Applied and Natural Science 10: 1276-1280.

[25] Kusmana, C. (2015): Keanekaragaman hayati (biodiversitas) sebagai elemen kunci ekosistem kota hijau. - Prosiding Seminar Nasional Masyarakat Biodiveritas Indonesia 1: 1747-175. 
[26] Lee, C. M., Kwon, T. S. (2012): Characterization of the butterfly community of a fragmented urban forest, Hongneung Forest. - Korean Journal Applied Entomology 51: 317-323.

[27] Lee, C. M., Kwon, T. S. (2013): Community structure, species diversity of insects (ants, ground beetle), and forest health in the Hongneung Forest. - Journal Korean for Society 102: 97-106.

[28] Lee, C. M., Kwon, T. S., Kim, S. S., Sohn, J. D., Lee, B.W. (2014): Effects of forest degradation on butterfly communities in the Gwangneung forest. - Entomology Science 17: 293-301.

[29] Lee, C. M., Park, J. W., Kwon, T. S., Kim, S. S., Ryu, J. W., Jung, S. J., Lee, S. K. (2015): Diversity and density of butterfly communities in urban green areas: an analytical approach using GIS. - Zoological Studies 54: 4: 1-12.

[30] Lestari, D. F., Putri, R. D. A., Ridwan, M., Purwaningsih, A. D. (2015): Butterfly diversity (Insect: Lepidoptera) at Alas Bromo Tourism Wana. - BKPH North Lawu, Karanganyar.

[31] Lewis, T. O. (2001): Effect of experimental selective logging on tropical butterflies. Conservation Biology 15(2): 389-400.

[32] Ludwig, J. A., Reynolds, J. F. (1988): Statistical Ecology. A Primer on Methods and Computing. - John Wiley and Sons, New York.

[33] MacArthur, R. H., Wilson, E. O. (1967): The Theory of Island Biogeography. - Princeton University Press, Princeton, NJ.

[34] Magurran, A. E. (1988): Ecological Diversity and Its Measurements. - Croom Helm Limited, London.

[35] Magurran, A. E. (2004): Measuring Biological Diversity. - Wiley-Blackwell, Malden.

[36] MCKinney, M. L. (2002): Urbanization, biodiversity, and conservation. - BioScience 52: 883-890.

[37] Motegi, N., Yanai, S. (2005): A study on the characteristics of bird distribution in rooftop vegetation in Tokyo Ward. - Jpn Inst Landscape Architecture 68: 597-600.

[38] Noerdjito, W. A., Aswari, P. (2003): Methods of Surveying and Monitoring Animal Populations: 4th Series: Papilionidae Butterflies. - Center for Biological Research and Development, LIPI, Bogor.

[39] Nurjanah, S. T. (2010): Biology of Troides helena helena dan Troides helena hephaestus (Papilionidae) in captivity. - Thesis, Bogor Agricultural University, Bogor.

[40] Odum, E. P. (1996): Basics of Ecology. 3th Ed. - Gadjah Mada University Press, Yogyakarta.

[41] Oktaviani, W., Rifanjani, S., Ardian, H. (2019): Diversity of butterflies species (Ordo: Lepidoptera) in Urban forests in Pontianak City. - Jurnal Hutan Lestari 7: 79-85.

[42] Peggie, D., Amir, M. (2006): Practical Guide to the Butterflies of Bogor Botanic Garden. - Pusat Penelitian biologi, LIPI, Cibinong, Indonesia.

[43] Peggie, D. (2014): Butterflies. - Pandu Aksara Publishing, Jakarta.

[44] Plona, M. B. (2002): Butterfly Monitoring Report. - Cuyahoga Valley National. http://www.nps.gov/cuva/management/rm/02butterflies.htm.

[45] Preeven, F. K., Haroon, F. P. (2015): Checklist of Butterfly (Insecta: Lepidoptera) Fauna of Tehsil Tangi, Khyber Pakhtunkhwan, Pakistan. - Department of Zoology, Shaheed Benazir Bhutto University, Khyber Pakhtunkhwan, Pakistan.

[46] Rahayu, S. E., Basukriadi, A. (2012): Abundance and diversity of butterfly species (Lepidoptera; Rhopalocera) in various habitat types in the Muhammad Sabki Urban Forest, Jambi City. - Biospecies 5: 40-48.

[47] Rahayuningsih, M., Oqtafiana, R., Priyono, B. (2012): Diversity of butterfly species in the superfamily Papilionoidae at Banyuwindu Hamlet, Limbangan Village, Limbangan District, Kendal Regency. - Journal MIPA 35: 11-20.

[48] Ramesh, T., Hussain, K. J., Selvanayagam, M., Satpathy, K. K., Prasad, M. V. R. (2010): Pattern of diversity, abundance and habitat associations of butterfly communities in 
heterogeneous landscape of the Department of Atomic Energy (DAE) Campus at Kalpakkam, South India. - International Journal of Biodiversity and Conservation 2: 7585.

[49] Rubèn, O. A., Ian, M. F. (2009): Living in the big city: effects of urban land-use on bird community structure, diversity, and composition. - Landscape Urban Plan 90: 189-195.

[50] Sarma, K., Kumar, A., Devi, A., Mazumdar, K., Krishna, M., Mudoi, P., Das, N. (2012): Diversity and habitat association of butterfly species in Foothills of Itanagar, Arunchal Pradesh. - Zoology 1: 67-77.

[51] Schulze, C. H., Fiedler, K. (1998): Habitat preferences and flight activity of Morphinae butterflies in a Bornean rain forest, with a note on sound production by adult Zeuxidia (Lepidoptera: Nymphalidae). - Malayan Biology 8: 800-809.

[52] Scott, J. (1986): The Butterflies of North America: A Natural History and Field Guide. Oxford University Press, USA.

[53] Shahabuddin, Schulze, C. H., Tscharnke, T. (2005): Changes of dung beetle communities from rainforests towards agroforestry systems and annual cultures in Sulawesi (Indonesia). - Biodiversity and Conservation 14: 863-877.

[54] Sharma, G., Joshi, P. G. (2009): Diversity of butterflies (Lepidoptera: Insecta) from Dholbaha dam (Distt. Hoshiarpur) in Punjab Shivalik, India. - Biological Forum an International Journal 1(2): 11-14.

[55] Sihombing, D. T. H. (2002): Hope Animals I: Introduction to Agriculture Science and Cultivation Technology. - Pustaka Wirausaha Muda, Bogor.

[56] Soeharto, T., Mardiastuti, A. (2003): Implementation of Convention CITES at Jakarta: Indonesia. - JICA, PLC, London.

[57] Speight, M. R., Hunter, M. D., Watt, A. D. (1999): Ecology of Insects: Concepts and Applications. - Blackwell Science, London.

[58] Sreekumar, P. G., Balakrishnan, M. (2001): Habitat and altitude preferences of butterflies in Aralam Wildlife Sanctuary, Kerala. - Journal Tropical Ecology 42: 277-281.

[59] Stat Soft (2001): Stastistica for Windows, 6.0. - Statsoft Inc. Tulsa, Oklohoma.

[60] Sutra, N. S. M., Dahelmi, S., Siti, S. (2012): Butterflies species (Rhopalocera) in Tanjung Balai Karimun, Kabupaten Karimun Regency, Riau Islands. - Jurnal Biologi Univ. Andalas 1: 35-44.

[61] Thangjam, R., Kadam, V., Hemochandra, I., Ramalaxmi, V., Krishna, D. G., Patnaik, L. (2018): Studies on the diversity and abundance of butterfly in and around CUTM, Paralakhemundi campus, Odisha (India). - Journal of Entomology and Zoology Studies 6: 2484-2491.

[62] Tsukada, E., Nishiyama, Y. (1981): Butterflies of the South East Asian Island, Part II Pieridae-Danaidae. - Palapa Co. Ltd., Minatok-Tokyo.

[63] Tsukada, E., Nishiyama, Y. (1982a): Butterflies of the South East Asian Island, Part I Papilionidae. - Palapa Co. Ltd., Minatok-Tokyo.

[64] Tsukada, E., Nishiyama, Y. (1982b): Butterflies of the South East Asian Island, Part III Satyridae-Lybytheidae. - Palapa Co. Ltd., Minatok-Tokyo.

[65] Tsukada, E., Nishiyama, Y. (1985): Butterflies of the South East Asian Island, Part IV Nympalidae (I). - Palapa Co. Ltd., Minatok-Tokyo.

[66] Tsukada, E., Nishiyama, Y. (1991): Butterflies of the South East Asian Island, Part V Nympalidae (II). - Palapa Co. Ltd., Minatok-Tokyo.

[67] Vane-Wright, R. I., de Jong, R. (2003): The butterflies of Sulawesi: annotated checklist for a critical island fauna. - Zoologische Verhandelingen 343: 3-267.

[68] Watanabe, M., Imoto, T. (2003): Thermoregulation and flying habits of the Japanese sulfur butterfly Colias erate (Lepidoptera: Pieridae) in an open habitat. - Entomology Science 6: 111-118. 